\title{
Pemanfaatan fitur media sosial Instagram dalam membangun personal branding Miss International 2017
}

\author{
Sella Efrida ${ }^{1}$, Anisa Diniati² \\ ${ }^{1}$ Institut Teknologi dan Bisnis Kalbis, Jakarta, Indonesia \\ ${ }^{2}$ Universitas Telkom, Bandung, Indonesia
}

\begin{abstract}
ABSTRAK
Media sosial saat ini selain sebagai media berkomunikasi dan berinteraksi, tetapi juga mendatangkan suatu fenomena baru sebagai wadah dalam melakukan personal branding. Salah satu media sosial yang sering digunakan dalam melakukan personal branding adalah Instagram. Kevin Liliana melalui akun Instagramnya @ kevinlln melakukan pemanfaatan fitur pada Instagram untuk menampilkan identitas dirinya sebagai seorang Miss International 2017. Tujuan penelitian ini adalah untuk mengetahui bagaimana personal branding yang dilakukan oleh Kevin Liliana selaku Miss International 2017 dengan memanfaatkan media sosial Instagram. Penelitian ini menggunakan paradigma konstruktivisme yang bertujuan untuk menafsirkan makna-makna yang dimiliki oleh informan tentang suatu fenomena personal branding yang dilakukan oleh Kevin Liliana selaku Miss International 2017 yang terdapat pada fitur Instagram. Penelitian ini menggunakan pendekatan kualitatif dengan jenis penelitian deskriptif. Teknik pengumpulan data penelitian ini berupa observasi, wawancara mendalam, dan dokumentasi. Hasil penelitian menunjukkan bahwa Kevin Liliana mendasari personal branding-nya secara authentic, dimana terdapat keselarasan antara apa yang ia tampilkan di media sosial dan kehidupan aslinya. Personal branding yang Kevin Liliana tampilkan sebagai Miss International 2017 yaitu sebagai beauty queen yang soft, humble, dan menonjolkan sisi behavior-nya. Kevin Liliana membangun personal branding melalui Instagram pribadinya @ kevinlln ini tidak hanya berupa mengunggah konten personal branding, tetapi juga dengan berinteraksi dengan para pengikutnya melalui fitur Instagram agar pesan personal branding-nya dapat lebih cepat dan mudah tersampaikan. Secara keseluruhan, Kevin Liliana berhasil melakukan personal branding di media sosial Instagram, walaupun terdapat kekurangan, seperti engagement pada konten kegiatan sosialnya tidak lebih banyak mendapat respon seperti like dan comment dari pengguna lain.
\end{abstract}

Kata-kata Kunci:Instagram; fitur instagram; media sosial; Miss International 2017; personal branding

\section{Utilization of Instagram features in building personal branding of}

\section{ABSTRACT}

Social media is not only used as a medium to communicate and interact with other people, but also brings a new phenomenon as a place to do personal branding. One social media that is often used in doing personal branding is Instagram. Kevin Liliana through herInstagram account@kevinlln used the features on Instagram to show her identity as a Miss International 2017. The focus of this research is to learn more about personal branding carried out by Kevin Liliana as Miss International 2017 using social media Instagram. In this study, researchers used the constructivism paradigm because this study aims to interpret the meanings possessed by informants about a phenomenon of personal branding conducted by Kevin Liliana as Miss International 2017 by utilizing Instagram social media features. This study uses descriptive qualitative with descriptive research types. This data collection technique consists of in-depth interview, observation, and documentation. The results showed that Kevin Liliana underlies her personal branding in an authentic way, where there is harmony between what she displays on social media and her real life. Personal branding that Kevin Liliana presents as Miss International 2017 is a beauty queen who is soft, humble, and accentuates her behavior. Kevin Liliana built her personal branding through her personal Instagram@kevinlln not only by uploading personal branding content, but also by interacting with her followers (followers) through the Instagram feature so that his personal branding messages can be faster and easier to convey. Overall, Kevin Liliana managed to do personal branding on Instagram social media, although there were deficiencies, such as engagement on the content of social activities did not get more responses such as likes and comments from other users.

Keywords: Instagram; instagram feature; Miss International 2017; personal branding; social media

Korespondensi: Sella Efrida, S.I.Kom., Institut Teknologi dan Bisnis Kalbis, Jl. Pulomas Selatan Kav. 22, Jakarta Timur 13210.Email: sellaefrida@gmail.com 


\section{PENDAHULUAN}

Setiap orang di dunia ini pasti mempunyai suatu keunikan tersendiri yang menjadi kelebihannya masing-masing. Keunikan seseorang tersebut dapat berasal dari wajah, nama, kebiasaan unik, sifat, karakter, prestasi, bakat dan hal lainnya. Seiring dengan berjalannya waktu, keunikan yang dimiliki oleh seseorang dapat terus berkembang menjadi suatu keahlian-keahlian khusus. Dengan adanya perkembangan keunikan tersebut, sebagian orang menyadari bahwa keunikan tersebut bukan hanya untuk menjadi pembeda dengan yang lain, tetapi dapat pula menjadi sebuah kelebihan yang dapat diperlihatkan dan ditampilkan kepada publik. Hal ini dikarenakan era yang terus berkembang ini, kompetisi antar individu semakin luas yang mengharuskan setiap orang untuk memiliki suatu kelebihan tersendiri sebagai modal bersaing dengan orang lain.

Banyak cara untuk menampilan keunikan dan kelebihan masing-masing, contohnya dengan melakukan personal branding. Setiap orang pasti mempunyai personal branding yang diperlihatkan kepada publik sebagai suatu identitas diri. Personal branding dapat dibangun melalui berbagai hal seperti memperlihatkan keahlian, kepribadian, serta keunikan karakter yang dapat dibungkus menjadi sebuah identitas dengan segala kelebihannya.

Sebuah penelitian menyebutkan bahwa para remaja mempresentasikan personal branding-nya dengan suatu tujuan, yaitu untuk dihargai (Heikkurinen, 2016). Presentasi personal branding tersebut dilakukan dengan membuat langkah strategis mengenai konten yang akan mereka tampilkan untuk diunggah ke akun sosial media Instagram mereka masingmasing. Dimana apa yang mereka unggah merupakan cerminan dari personal branding dan identitas mereka sebagai seorang remaja. Setiap orang dengan identitas pribadinya mampu memberikan respon emosional pada orang lain tentang kualitas serta nilai yang dimiliki oleh orang tersebut (Tamimy, 2017). Personal branding sendiri sangatlah penting dikarenakan dapat menambah nilai seseorang di mata banyak orang. Selain itu, dengan adanya personal branding, seseorang menjadi mudah diingat karena suatu hal yang sangat 'khas' dari dirinya.
Kegiatan personal branding kini dipermudah dengan adanya perkembangan teknologi digital seperti media sosial. Sebelum media sosial hadir ditengah masyarakat, kegiatan personal branding yang dilakukan hanya sebatas menggunakan media tradisional yang sifatnya satu arah dan tidak menimbulkan suatu interaksi di dalamnya. Kegiatan personal branding melalui media tradisional dapat dilakukan dengan berbagai cara yaitu seperti menerbitkan sebuah buku, publikasi melalui artikel di majalah atau koran, menjadi pembicara di depan umum, dan lain sebagainya.

Hal ini tentunya berbeda dengan munculnya media sosial. Melalui media sosial, banyaknya individu yang memanfaatkan fenomena ini untuk melakukan kegiatan personal branding tidak hanya di kehidupan sehari-hari secara offline, tetapi juga online. Bentuk komunikasi yang dihasilkan juga bersifat terbuka bagi siapa saja yang ingin melakukan suatu komunikasi ataupun saling berbagi informasi. Penggunaan media sosial dalam hitungan waktu berjalan sangat cepat. Bahkan seseorang bisa menjadi lebih dikenal oleh publik secara cepat hanya dengan beberapa hitungan waktu.

Media sosial mempunyaikekuatan dan peran khusus dalam membentuk personal branding seseorang, dimana apa yang diperlihatkan oleh seseorang di media sosial akan mendatangkan identitas dan representasi diri dari seseorang tersebut. Personal branding melalui media sosial merupakan hal yang begitu penting bagi masyarakat, salah satu contohnya adalah saat ini media sosial banyak dipergunakan oleh banyak perusahaan dalam proses perekrutan karyawan dan juga melakukan penyeleksian berdasarkan identitas dan apa yang seseorang ditampilkan di media sosialnya sebagai representasi diri.

Kegiatan personal branding melalui media sosial juga dapat dimanfaatkan sebagai sarana pembentukan identitas dan representasi diri yang akan ditampilkan kepada orang lain dengan memberi kesan keunikan dan kekhasan khusus mengenai diri seseorang. Selain itu, peran media sosial dalam pembentukan personal branding juga dapat mendatangkan manfaat sebagai ladang bisnis, seperti contoh banyak sekali brand atau perusahaan ternama yang menggunakan seseorang tertentu yang dinilai mempunyai personal branding yang baik dan mempunyai karakter atau ciri khas yang sesuai dengan brand atau perusahaan tertentu untuk 
mempromosikan produk atau jasanya hanya dengan melalui foto dan video yang di upload melalui media sosialnya. Banyak sekali contoh orang-orang yang sukses melakukan personal branding dengan baik, diantaranya adalah Syahrini. Syahrini kerap mempresentasikan dirinya sebagai seorang selebriti yang selalu tampil glamour dan mewah. Sebuah pernyataan menyebutkan bahwa:

"Syahrini merupakan penyanyi muda yang dikenal oleh hampir semua anak muda Indonesia karena kontroversinya yang kerap menggegerkan. Ia misalnya kerap menjadi trend setter, mulai dari gaya berpakaian, gaya rambut, hingga celetukan seperti 'sesuatu' atau 'cetar-membahana' dan lain-lain. Ia juga memunculkan 'bulu mata anti badai', 'bulu mata lentik', dan 'jambul katulistiwa” (Haroen, 2014).

Celetukannya tersebut cepat mendapat respon yang cepat dari masyarakat dan menjadi suatu hal yang viral dan terkenal dikalangan masyarakat di Indonesia. Hal tersebut dikarenakan kemampuannya untuk melakukan personal branding yang baik dengan menampilkan sisi khas dan keunikannya kepada masyarakat melalui akun sosial media miliknya. Hal inilah mengapa saat ini Syahrini dianggap sebagai selebriti yang mempunyai tingkat awareness tinggi pada media sosialnya dan banyak menimbulkan perhatian dari berbagai media maupun masyarakat mengenai apa yang ia tampilkan melalui media sosialnya.

Berdasarkan contoh kasus tersebut, maka pemilihan media sosial dalam melakukan personal branding merupakan hal penting. Pemilihan media sosial yang tepat dan sesuai akan menghantarkan proses personal branding menjadi lebih efektif dan berjalan dengan lancar. Intagram merupakan media sosial yang saat ini banyak digunakan dalam melakukan personal branding. Kevin Systrom dan Mike adalah orang yang pertama kali merilis Instagram. Fitur spesifik yang mereka rilis pertama kali ialah fitur foto dan video yang tentunya dapat digunakan dengan mudah, cepat, serta canggih. Instagram sendiri dianggap menjadi media yang saat ini paling popular dan diminati oleh masyarakat (Pratama, 2018).

Hal ini terbukti dengan adanya data yang dilansir dari www.liputan6.com, bahwa pengguna Instagram pada Juni 2018 meningkat pesat dan tembus sampai dengan satu miliar

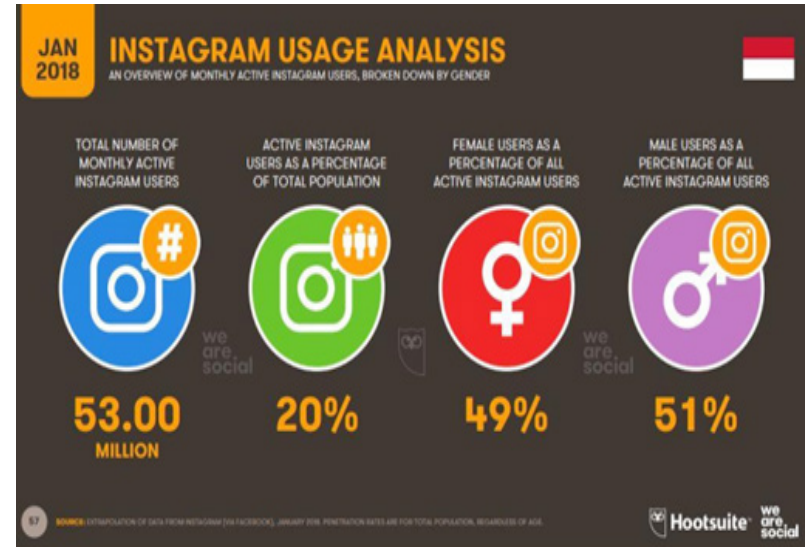

Sumber: www.tek.id, 2018

Gambar 1 Jumlah Pengguna Instagram di Indonesia

pengguna yang berasal dari seluruh dunia. Jumlah tersebut menunjukkan kenaikan yang sangat signifikan, mengingat pada September 2017 mereka masih memiliki 800 juta pengguna. Dari data tersebut dapat terlihat bahwa hingga kini Instagram menjadi salah satu media yang banyak diakses oleh masyarakat berbagai kalangan di seluruh dunia termasuk Indonesia (Jeko, 2018).

Berdasarkan hasil analisa data sepanjang tahun 2018 terkait penggunaan Instagram di berbagai negara (Indonesia, Malaysia, Filipina, dan Singapura), 53 juta pengguna aktif bulanan berasal dari Indonesia (We Are Social, 2018). Bila melihat data dari Badan Perencanaan Pembangunan Nasional (Bappenas), jumlah penduduk Indonesia pada tahun tersebut sebanyak 265 juta jiwa, artinya pengguna aktif Instagram di Indonesia pada tahun 2018 mencapai 20 persen. Jumlah tersebut terdiri dari 133,17 juta jiwa laki-laki dan 131,88 juta jiwa perempuan (Databoks, 2018).

Citra diri, keunikan, dan keahlian yang ditunjukkan oleh para pengguna Instagram di akunnya menunjukkan bahwa Instagram mampu memunculkan sebuah fenomena baru di tengah masyarakat luas. Berkat banyaknya fitur canggih yang ditawarkan, hal ini memudahkan para penggunanya untuk saling mengekspresikan dirinya kepada publik, kemudahan berkomunikasi, berinteraksi serta sarana penyampaian pesan dan informasi. Fenomena ini menunjukkan bahwa jejaring sosial Instagram tidak hanya sebagai sarana berbagi karya visual dan berkomunikasi, tetapi juga mulai dimanfaatkan sebagai sarana 
membangun personal branding.

Instagram berasal dari penggabungan kata "instant" dan "gram" yang berasal dari kata "telegram". Artinya, aplikasi ini diharapkan dapat memberikan informasi cepat dan tersaji secara instan seperti telegram (Pratama, 2018). Media sosial Instagram sendiri adalah media yang mengunggulkan konten visualnya, baik itu berupa gambar maupun video (Tamimy, 2017). Berdasarkan penjabaran di atas, dapat dilihat bahwa Instagram memberikan peluang besar bagi para penggunaya untuk mengambil hingga berbagi konten foto dan video kepada para pengguna lainnya.

Pemanfaatan media sosial Instagram sebagai tempat atau wadah dalam melakukan personal branding banyak dilakukan oleh banyak orang. Salah satunya Kevin Liliana selaku Miss International 2017 pertama asal Indonesia. Kevin Liliana yang lahir pada tanggal 5 Januari 1996, diusia nya yang masih muda ini sudah mendapatkan banyak prestasi dari tingkat nasional hingga internasional. Mulai dari mendapat gelar Gadis Sampul Persahabatan 2012, Wakil 1 Mojang Kota Bandung 2015, Putri Indonesia Jawa Barat 2017, Putri Indonesia Lingkungan 2017 (Runner Up 1 Putri Indonesia 2017) hingga menjadi wanita Indonesia pertama yang memenangi ajang beauty pageant Miss International 2017.

Kevin Liliana selaku Miss International 2017 memiliki akun Instagram dengan username @ kevinlln. Akun tersebut memiliki 521 ribu pengikut (followers) dan sudah verifed. Terlihat dalam akun Instagram @kevinlln tersebut selalu aktif mengunggah foto yang berkaitan dengan aktivitasnya. Mulai dari konten yang berisikan aktivitas pribadi, pekerjaan, kegiatan sosial dan konten lainnya.

Miss International (nama resmi: Miss International Beauty Pageant) merupakan ajang kecantikan yang berasal dari negara Jepang. Miss International Beauty Pageant dibentuk di Amerika Serikat, di Long Beach, California pada tahun 1960. Miss International Beauty Pageant telah mengembangkan berbagai pertukaran budaya, dengan slogan "pemahaman yang benar tentang Jepang di komunitas internasional" dan "realisasi perdamaian dunia melalui saling pengertian", sebagai bisnis kontribusi internasional. Ajang kecantikan ini memainkan peran penting dalam pariwisata periklanan di Jepang, dengan memperluas lingkaran kegiatan niat baik dari berbagai perwakilan dari masingmasing negara.

Gelar yang Kevin Liliana dapatkan tersebut, tentunya ia banyak melakukan aktifitas-aktifitas seperti menjadi pembicara diberbagai seminar, menghadiri crowning moment diberbagai negara, menjadi brand ambassador make up Mustika Ratu yang merupakan sponsor utama Putri Indonesia dan juga Miraiz Japan (air mineral asal Jepang) serta Miss Paris Group (tempat Spa di Jepang) yang merupakan sponsor dari Miss International Beauty Pageant. Kevin Liliana juga ditunjuk sebagai Tourism Brand Ambassador for Asia-Pacific (Termasuk China dan USA) untuk Indonesia oleh Minister of Tourism. Selain aktif di dunia pageant, Kevin Liliana juga aktif melakukan kegiatan sosial, diantaranya bergabung dalam komunitas sosial Matahari Kecil Indonesia dan JKBBE - Earth Hour Bandung.

Sebagai seseorang yang sudah membanggakan Indonesia di tingkat Internasional, tentunya Kevin Liliana sangat dikenal oleh masyarakat. Oleh karena itu ia memanfaatkankan media sosial Instagram sebagai tempat berbagi informasi dan mengabadikan berbagai kegiatannya, mulai dari kegiatan sehari-hari yang ia lakukan sampai aktifitas pekerjaan serta kegiatan sosial yang ia lakukan. Personal Branding sekilas yang tampak pada akun Instagram pribadi Kevin Liliana @ kevinlln adalah sebagai beauty queen yang humble dan menampilkan keaktifannya dalam menjadi pembicara maupun tamu undangan di berbagai acara. Hal ini dapat dilihat dari komposisi foto yang ia unggah ke dalam akun Instagramnya dimana ia selalu mengunggah semua aktifitas yang ia lakukan.

Ketertarikan peneliti untuk melakukan penelitian tentang topik ini dikarenakan ingin menggali lebih dalam bagaimana Kevin Liliana yang merupakan seorang public figure mampu melakukan personal branding dalam hal membentuk identitas dan representasi dirinya melalui akun Instagramnya. Selain itu, tujuan dari penelitian ini adalah untuk mengetahui bagaimana sebuah aplikasi Instagram mampu membentuk personal branding seseorang. Melalui penelitian ini, diharapkan dapat mendatangkan manfaat yakni menjabarkan serta memberikan gambaran yang jelas dan juga tepat bagaimana peran media sosial dalam membangun personal branding Kevin Liliana 
selaku Miss International 2017 yang tentunya akan ditampilkan kepada publik sebagai bentuk dari representasi diri.

Berdasarkan uraian latar belakang di atas, bahwa di era perkembangan teknologi yang terus berkembang ini, pemanfaatan Instagram tidak hanya sebagai media dalam melakukan komunikasi dan interaksi, tetapi juga sebagai wadah dalam melakukan personal branding. Berdasarkan uraian tersebut, maka diperlukan sebuah pengkajian mengenai bagaimana personal branding yang dilakukan oleh seorang public figure dengan memanfaatkan peran media sosial Instagram demi mendapatkan persepsi positif dari publik, sehingga dari hal tersebut dapat terlihat personal branding seperti apa yang ingin ditampilkan. Dengan demikian, peneliti mengangkat penelitian ini dengan judul Pemanfaatan Media Sosial dalam Membentuk Personal Branding Miss International 2017.

Peneliti menetapkan batasan penelitian ini hanya pada pemanfaatan media sosial (Instagram) dalam membangun personal branding yang dilakukan oleh Kevin Liliana selaku Miss International 2017. Adapun tujuan penelitian ini adalah untuk mengetahui personal branding Kevin Liliana sebagai Miss International 2017 dan pemanfaatan fitur media sosial Instagram dalam membangun personal branding Kevin Liliana sebagai Miss International 2017. Manfaat dari penelitian ini diharapkan dapat memberikan sumbangan pada perkembangan ilmu komunikasi, khususnya mengenai pemanfaatan fitur media sosial dalam membangun personal branding public figure; dapat memberikan rekomendasi kepada kegiatan penelitian berikutnya yang mempunyai topik penelitian yang sama; serta mampu memberikan masukan kepada para pembaca untuk mengembangkan personal branding-nya melalui pemanfaatan media sosial, khususnya Instagram.

\section{METODE PENELITIAN}

Paradigma dalam penelitian ini adalah paradigma konstruktivisme, dimana peneliti memiliki tujuan untuk menafsirkan maknamaknatentang personalbrandingyangdilakukan oleh Kevin Liliana selaku Miss International 2017 dengan memanfaatkan fitur media sosial Instagram. Dalam paradigma konstruktivisme, pengetahuan adalah hasil dari konstruksi manusia, sehingga dapat digambarkan sebagai hasil dari tindakan manusia itu sendiri. Namun, paradigma konstruktivisme tidak pernah dipertanggungjawabkan sebagai kebenaran yang tetap, tetapi merupakan permasalahan dan selalu berubah (Gunawan, 2013).

Pendekatan kualitatif yang peneliti gunakan bertujuan untuk mengetahui informasi tentang bagaimana cara Kevin Liliana membangun personal branding melalui media sosial Instagram miliknya, yaitu@kevinlln. Pendekatan kualitatif fokus dalam mendalami dan menyelidiki pemahaman tentang sebuah fenomena sosial yang berkaitan dengan masalah manusia (Noor, 2015).

Studi deskriptif yang peneliti pilih memiliki tujuan untuk mendeskripsikan secara sistematis mengenai bagaimana Kevin Liliana selaku Miss International 2017 membangun personal branding melalui akun media sosial Instagram pribadinya @kevinlln. Deskripsi tersebut diawali dengan bagaimana personal branding yang Kevin Liliana ingin tampilkan dengan memanfaatkan fitur-fitur pada Instagram. Penelitian dengan studi deskriptif mengungkapkan dan menyajian fenomena secara faktual, akurat, serta sistematis tentang fakta dan sifat-sifat populasi tertentu (Usman \& Akbar, 2006).

Dalam menentukan informan, peneliti melakukan pertimbangan tertentu dengan cara purposive sampling, yaitu menentukan informan berdasarkan kriteria-kriteria tertentu yang peneliti tetapkan sebelumnya. Adapun kriteria dalam memilih informan dan narasumber, diantaranya informan kunci (Key Informan): Informan kunci yang peneliti pilih adalah Kevin Liliana (23 tahun), karena ia menggunakan media sosial Instagram sebagai wadah dalam melakukan personal branding; mempunyai ciri khas tersendiri yang menjadi nilai tambah dalam dirinya, dan pembeda dengan orang lain; aktif dalam menggunakan Instagram; dan memanfaatkan fitur Instagram dalam membangun personal branding.

Selain informan kunci, terdapat juga informan pendukung dalam penelitian ini adalah Nina Nur Azizah (24 tahun) sebagai Chaperone dan Staff Yayasan Puteri Indonesia. Alasan peneliti memilih Nina sebagai informan pendukung, karena ia merupakan orang terdekat Kevin Liliana dan mengetahui aktivitas keseharian Kevin Liliana selama 
menjabat sebagai Miss International 2017. Adapun narasumber atau pakar dalam penelitian ini adalah mereka yang mengerti mengenai personal branding secara mendalam dan mengerti mengenai media sosial secara mendalam. Narasumber berikutnya adalah pakar di bidang personal branding dan Psikolog, yaitu Dewi Haroen (56 tahun); serta Pengamat Medis Sosial dan Konsultan, yaitu Abang Edwin Syarif Agustin (49 tahun).

Adapun teknik pengumpulan data yang dilakukan terdiri atas: (1) Observasi nonpartisipan, dimana peneliti hanya sebatas mengamati perilaku dan sikap dari Kevin Liliana terkait personal branding yang ingin ia sampaikan. Observasi nonpartisipan berarti peneliti selaku pengamat tidak ada keterlibatan langsung selama informan melakukan berbagai kegiatan (Suwendra, 2018); (2) Wawancara. Wawancara yang peneliti gunakan ialah semiterstruktur (semistructure interview) dengan tujuan agar peneliti bisa mengungkapkan masalah dengan lebih terbuka. Untuk mengungkapan permasalahan tersebut peneliti mengajukan berbagai pertanyaan secara terbuka kepada informan dan narasumber untuk mengemukakan pendapat dan ideidenya. Wawancara dapat didefinisikan sebagai pertukaran informasu maupun ide melalui tanya jawab antara dua orang (Sugiyono, 2013); dan

(3) Dokumentasi. Dokumentasi bermanfaat untuk memperkuat temuan data. Adapun bentuk dokumentasi yang digunakan berupa buku (literatur), data internet, dan foto yang berhubungan dengan penelitian ini.

Teknik analisis data yang digunakan adalah tahapan atau alur yang dikemukakan oleh Miles dan Huberman (Sugiyono, 2013). Mereka menyatakan bahwa proses analisis data kualitatif dilakukan dengan beberapa tahapan yang terdiri dari data reduction (reduksi data), data display (penyajian data), dan conclusion drawning (verifikasi). Sedangkan untuk menguji kvaliditas atau redibiltas hasil penelitian, peneliti melakukan teknik triangulasi sumber dengan mengecek data yang sudah diperoleh dari berbagai sumber, baik dengan sumber yang sama maupun dengan sumber yang berbeda (para pakar/ahli). Setelah itu, data yang telah didapatkan dari informan dan narasumber tersebut dideskripsikan, dikategorisasikan, lalu dipilih mana pandangan yang sama, yang berbeda, hingga yang lebih spesifik (Fuad \&
Nugroho, 2014).

\section{HASIL DAN PEMBAHASAN}

Kevin Liliana merupakan wanita pertama asal Indonesia yang memenangkan ajang major beauty pageant, Miss International. Selama satu tahun menjabat sebagai Miss International 2017, tentunya Kevin Liliana banyak melakukan aktifitas yang berkaitan dengan gelarnya. Sebagai seorang beauty queen yang notabanenya adalah seorang public figure, Kevin Liliana menyadari bahwa pentingnya membangun personal branding untuk dapat menunjukkan identitasnya kepada orang lain. Menurutnya, apa yang ditampilkan akan menjadi representasi mengenai dirinya sendiri sebagai suatu identitasnya sebagai public figure, dan tentunya apa yang ditampilkan tersebut akan dinilai oleh orang lain.

Hasil penelitian yang peneliti dapatkan diketahui bahwa Kevin Liliana membangun personal branding-nya secara authentic dan sesuai dengan apa yang menjadi kepribadian aslinya. Personal branding yang Kevin Liliana bangun adalah dengan memanfaatkan atau mengoptimalkan fitur yang ada di Instagram. Secara garis besar, media sosial sebagai media online mampu membuat para penggunanya (user) melakukan beragam aktivitas seperti berbagi, berpartisipasi, dan menciptakan konten berupa blog, wiki, forum, jejaring sosial, dan ruang dunia virtual yang disokong oleh teknologi multimedia yang kian canggih (Abbas, 2014).

Media sosial merupakan media yang memiliki banyak manfaat. Pemanfaatan fitur Instagram yang dilakukan oleh Kevin Liliana dapat dilihat dari hasil wawancara yang peneliti lakukan dengannya secara langsung dan beberapa informan pendukung lainnya, serta observasi yang peneliti lakukan secara langsung di lapangan. Kevin Liliana membangun personal branding-nya sebagai seorang beauty queen soft, humble dan lebih menonjolkan sisi behavior-nya disamping beauty dan brain. Personal branding-nya tersebut juga authentic, dimana tidak palsu dan sesuai dengan bagaimana dirinya yang sebenarnya. Hal ini selaras dengan apa kenyataan bahwa personal branding yang asli yang dibentuk haruslah bersumber dari bukti-bukti yang otentik, nyata dan asli (Haroen, 2018). 
Authenticity yang dimiliki oleh Kevin Liliana dibentuk dari kepribadian alamiah dari dalam dirinya hingga akhirnya mencerminkan karakter, nilai-nilai, dan visi yang dimiliki oleh pribadi orang tersebut (Butar \& Ali, 2018). Berdasarkan hasil penelitian yang peneliti dapatkan, walaupun Kevin Liliana dalam membangun personal branding sebagai Miss International 2017 dibantu oleh pihak Yayasan Puteri Indonesia (YPI), tidak merubah apapun yang menjadi identitas asli dari Kevin Liliana. Personal branding Kevin Liliana tersebut dilandasi oleh visi yang ia miliki yaitu sebagai pribadi yang mempunyai kepribadian yang baik dan selalu positif serta humble kepada siapa saja.

Nilai yang dibentuk oleh Kevin Liliana selaku Miss International 2017 adalah sebagai seorang beauty queen yang berprestasi mengharumkan nama Indonesia dimana ia satu-satunya wanita Indonesia yang berhasil memenangkan ajang Miss International dimana selalu menampilkan konten yang positif dan menginspirasi selama ia menjabat di akun media sosial Instagramnya@kevinlln. Menurut Dewi Haroen selaku Pakar personal branding, dalam membangun personal branding diperlukan analisis SWOT untuk mengetahui apa yang menjadi strengths, weakness, opportunities dan threats diri seseorang dalam membangun suatu personal branding. Kevin Liliana dalam membangun personal branding-nya juga dilandasi pada SWOT yang diungkapkan oleh Dewi Haroen selaku Pakar personal branding.

Pertama, strengths yang Kevin Liliana miliki yaitu kemampuannya yang Kevin Liliana miliki yaitu kemampuannya untuk menjadi seorang pembicara, keahliannya dibidang modeling dan bakatnya dalam seni daerah Jawa Barat. Selain itu, Kevin Liliana juga memiliki kelebihan dalam melakukan personal branding yang lainnya yaitu Kevin Liliana merupakan wanita Indonesia yang memenangkan ajang Miss International yang tentunya membanggakan nama Indonesia. Kedua weakness, Kevin Liliana menyadari apa yang menjadi kelemahannya yaitu kurang mampu meng-ekspos diri diri di media sosial, namun Kevin Liliana mampu mengatasi weaknessnya tersebut karena dirinya sadar bahwa dalam membangun personal brandingnya mealui jejaring sosial, diperlukan adanya konten yang menunjukkan identitas dari dirinya.
Ketiga opportunities, Kevin Liliana menganalisis apa yang menjadi peluangnya dalam membangun suatu personal branding. Misalnya seperti undangan berbagai media atau event dan tawaran job lainnya yang dapat meningkatkan karirnya. Keempat threats, yaitu berupa ancaman yang Kevin Liliana mungkin dapatkan dalam membangun personal branding-nya sebagai Miss International 2017. Ancaman tersebut seperti adanya perbedaan makna dan persepsi mengenai apa yang Kevin Liliana tampilkan sebagai suatu identitas dirinya dalam personal branding-nya.

Selain analisis SWOT, Dewi Haroen selaku Pakar personal branding memaparkan bahwa dalam membangun personal branding dibutuhkan tiga hal lainnya, yaitu $3 \mathrm{~W}$ yang berupa "who you are", "what you do" dan "what makes you different". Kevin Liliana dalam melakukan personal branding-nya juga memiliki tiga hal tersebut, pertama "who you are" yang dimana Kevin Liliana menampilkan personal branding-nya sebagai seorang beauty queen, yaitu Miss International 2017 asal Indonesia. Kedua "what you do", yaitu Kevin Liliana menampilkan apa yang menjadi karakter dan identitas dirinya sebagai Miss International 2017, seperti kegiatan apa saja yang ia lakukan dan hal lainnya. Ketiga "what makes you different”, yaitu Kevin Liliana ingin menampilkan diri sebagai beauty queen yang humble kepada semua orang dan Kevin Liliana merupakan Miss International yang paling stylist dari segi berpenampilan.

Personal branding juga memiliki tiga faktor penting yang harus diperhatikan dalam memperkuat personal brand, yaitu pertama adalah kekhasan. Personal brand yang kuat mampu fokus terhadap sesuatu yang khas atau spesifik sehingga terlihat perbedaannya dibandingkan dengan orang lain. Keunikan lainnya seperti keahlian, tampilan fisik, dan kualitas kepribadian dapat direpresentasikan sebagai kekhasan dari individu tersebut (Haroen, 2018). Kevin Liliana dalam membangun personal branding-nya memiliki suatu kekhasan berupa kualitas dirinya dimana apa yang menjadi keahliannya di bidang beauty pageant dapat mendatangkan kebanggaan bagi negara Negara Indonesia karena ia berhasil memenangkan ajang Miss International Beauty Pageant.

Faktoryang keduayaiturelevansi. Relevansi 
karakter adalah keahlian yang dimiliki oleh seorang individu, dimana personal brand bisa dianggap kuat ketika keahlian tersebut dianggap penting bagi masyarakat (Haroen, 2018). Kevin Liliana dalam membangun personal brandingnya mempunyai relevansi antara gelar yang ia dapat, kepribadian aslinya dan hal yang ingin ia tampilkan sebagai personal brandingnya. Ketiga hal tersebut mempunyai relevansi dimana sebagai seorang beauty queen, Kevin Liliana harus memiliki suatu perlaku yang baik karena dianggap sebagai suatu public figure yang tentunya menjadi contoh yang baik bagi khalayak luas. Hal tersebut mempunyai kesesuaian dengan kepribadian asli dan personal branding yang ingin Kevin Liliana tampilkan sebagai Miss International 2017 yaitu sebagai pribadi yang menonjolkan sisi behavior dengan cara selalu santun, sopan serta humble kepada siapa saja.

Faktor ketiga adalah konsistensi. Personal brand yang kuat dihasilkan dari upaya branding yang konsisten atau terus menerus (Haroen, 2018). Kevin Liliana secara konsisten menampilkan konten yang berhubungan dengan personal branding di akun pribadinya @ kevinlln. Dalam menampilkan konten tersebut, Kevin Liliana juga berusaha sebisa mungkin tepat waktu dalam mengunggahnya agar tidak terkesan late post.

Sesuai dengan tujuan penelitian yang mengarah pada mengetahui bagaimana Kevin Liliana selaku Miss International 2017 membangun personal branding-nya dengan pemanfaatan media sosial Instagram ini didahului dengan pemenuhan terhadap konsep personal branding yang dibutuhkan seseorang untuk dapat melakukan personal branding. Konsep personal branding yang peneliti gunakan disini ialah personal branding yang dikemukakan Peter Montoya. Montoya menyebutkan bahwa terdapat delapan konsep pembentukan personal branding (the eight laws of personal branding). Delapan konsep tersebut terdiri dari spesialisasi (the law of specialization), kepemimpinan (the law of leadership), kepribadian(the law of personality), perbedaan (the law of distinctiveness), the law of visibility, kesatuan (the law of unity), keteguhan (the law of persistence), dan nama baik (the law of goodwill) (Haroen, 2014).

Penjelasan Montoya terkait konsep the law of specialization bahwa ketepatan seseorang pada spesialisasi tertentu menunjukkan personal brand yang khas dan hebat. Ketepatan spesialisasi tersebut dapat terkonsentrasi pada keahlian, kekuatan hingga pencapain yang dilakukan oleh individu tersebut (Haroen, 2014). Tentunya sebagai seorang beauty queen dengan gelar Miss International 2017 yang berhasil Kevin Liliana dapatkan, ia menampilkan apa yang menjadi spesialisasinya. Spesialisasi dapat dilakukan dengan menunjukkan ability, behavior, lifestyle, mission, product, profession, dan service (Haroen, 2014). Spesialisasi yang Kevin Liliana tunjukkan apa yang menjadi spesialisasinya dengan menunjukkan behavior dan profession-nya. Dimana behavior nya yang sejalan dengan personal branding-nya yang menampilkan diri sebagai beauty queen yang humble dan menjunjung tinggi sopan santun dan untuk profession-nya berupa gelarnya sebagai Miss International 2017.

Berdasarkan konsep the law of specialization tersebut, Kevin Liliana berusaha untuk menampilkan spesialisasi dirinya agar lebih baik. Hal tersebut sesuai dengan unggahan Kevin Liliana pada akun media sosial Instagramnya@kevinlln, yang selalu menampilkan apa yang menjadi spesialisasinya, yaitu sebagai seorang pembicara diberbagai acara dan dibidang modelling untuk pergeraian fashion show. Menurut analisis peneliti, apa yang Kevin Liliana lakukan tersebut merupakan salah satu upaya nya untuk dapat menampilkan apa yang menjadi spesialisasinya agar dapat menarik perhatian orang lain terhadapnya. Peneliti juga menganalisis bahwa spesialisasi yang dimiliki Kevin Liliana secara langsung dapat menarik perhatian dan membuat khalayak mengingat profesinya dan kelebihan yang ia miliki sebagai Miss International 2017.

Keahliannya tersebut, Kevin Liliana sering menjadi pembicara diberbagai acara atau forum serta juga menjadi mentor bagi penerusnya dalam hal catwalk, photoshoot dan hal lain yang berkaitan dengan beauty pageant. Menurut Montoya, kekuasaan dan kredibilitas bisa menjadi pelengkap bagi personal brand seseorang agar dapat memposisikan orang tersebut sebagai pemimpin yang terbentuk dari kesempurnaan seseorang (Haroen, 2014). Walaupun demikian, sisi kepemimpinan (the law of leadership) Kevin Liliana dalam membangun personal branding-nya kurang ia tampilkan. Walaupun Kevin Liliana mempunyai 
kredibilitas dalam menjadi keynote speaker dalam acara dan membantu para penerusnya dalam hal catwalk, tapi menurutnya untuk sisi leadership bukanlah hal yang ia perhitungkan untuk ditampilkan dalam hal membangun personal branding-nya. Berdasarkan hal tersebut peneliti dapat menyatakan bahwa walaupun Kevin Liliana memenuhi bagian kepemimpinan (the law of leadership), tapi hal tersebut tidak ia aplikasikan kedalam personal branding-nya sebagai Miss International 2017.

Hasil penelitian dalam jurnal yang peneliti rujuk sebagai bahan referensi juga menunjukkan bahwa Laudya Cynthia Bella berupaya membangun personal brandingnya dengan memanfaatkan fitur-fitur dalam akun Instagram bisnis kuenya yaitu @ BandungMakuta. Pembentukan personal branding tersebut juga menggunakan unsur 8 konsep personal branding, di antaranya adalah spesialisasi dimana unggahan foto yang menggunakan Bahasa Sunda mencirikan bahwa Bella asli dari Sunda, Bandung (Soraya, 2017). Hal ini menunjukkan bahwa konsep spesialisasi penting dimiliki agar publik dapat mengetahui kekhasan yang dimiliki oleh seseorang atau brand yang ingin dipromosikan.

Konsep selanjutnya adalah the law of personality. Berdasarkan kepribadian yang diungkapkan oleh Montoya, sosok kepribadian yang natural lalu hadir dengan kekuranga yang dimiliki mampu membentuk sebuah personal brand yang hebat (Haroen, 2014). Kepribadian yang dibentuk Kevin Liliana adalah sebagai Kevin sebagai pribadi yang selalu berfikir positif, berperilaku sopan dan humble kepada semua orang. Hal ini sesuai dengan apa yang Kevin Liliana unggah dalam akun pribadi Instagram@kevinlln yang lebih mengutamakan sisi behavior dimana yang merupakan identitas diri yang ingin ia tampilkan sebagai Miss International 2017.

Apa yang Kevin Liliana tampilkan tersebut sesuai dengan apa yang menjadi kepribadian aslinya, karena keseharian yang ia jalani sesuai dengan kepribadian yang ia tampilkan sebagai personal branding-nya. Peneliti dapat menyimpulkan bahwa kepribadian yang Kevin Liliana tampilkan authentic dengan apa yang menjadi kepribadian aslinya. Hal ini terlihat dari konten-konten yang ia tampilkan dalam Instagram pribadinya@kevinlln dimana ia mengunggah foto yang menampilkan kepribadiannya yang sopan dan tidak terdapat konten yang bersifat negatif.

Konsep selanjutnya the law of distinctiveness. Menurut Montoya, kemampuan seseorang ketika mampu menampilkan dirinya dengan cara yang khas atau berbeda dari orang lain artinya ia telah mampu membentuk personal brand-nya secara efektif (Haroen, 2014). Artinya, personal branding memang perlu dipublikasikan melalui cara yang khas, dalam hal ini Kevin Liliana menunjukan perbedaan dalam membangun personal branding-nya dengan tidak hanya mengenalkan apa yang menjadi "brand" nya sebagai seorang Miss International 2017 dengan menampilkan konten yang positif dan selaras dengan personal branding-nya, tetapi juga melakukan interaksi dengan orang lain melalui fitur Instagram agar pesan personal branding-nya dapat lebih mudah tersampaikan. Menurut peneliti, adanya perbedaan dalam memperkenalkan brand tersebut yang ditunjukan oleh Kevin Liliana menjadikan personal branding yang ia lakukan terkesan lebih efektif. Dalam membentuk personal branding, hal ini merupakan suatu keharusan sehingga personal branding yang tercipta bisa menjadi kuat.

Pada konsep The law of visibility, untuk menuju personal branding dikenal oleh banyak orang, maka personal brand yang dibangun harus tampak konsistensinya secara terus menerus (Haroen, 2014). Melalui akun Instagram pribadinya @kevinlln, Kevin Liliana aktif mengunggah foto dan video baik kegiatannya sebagai Miss International 2017 maupun kegiatan kesehariannya agar dapat dilihat secara terus menerus oleh publik hal ini termasuk kedalam upaya yang dilakukan oleh Kevin Liliana dalam memperlihatkan personal branding yang ia ingin bentuk. Dalam ingin menampilkan diri sebagai Miss International yang humble, dan menampilkan sisi behaviornya, Kevin Liliana juga menunjukkan personal branding-nya tersebut dengan cara memperlihatkan hal-hal yang positif sebagai Miss International 2017.

Hal ini terlihat pada akun Instagram pribadinya@kevinlln yang memperlihatkan konten-konten positif seperti memperlihatkan kegiatan sosial yang ia lakukan, dan juga bersifat ramah kepada siapapun baik secara langsung maupun di media sosial. Terlihat pada akun Instagram pribadinya@kevinlln, bahwa 
dirinya kerap membalas komentar-komentar positif yang diberikan oleh pengguna orang lain, hal tersebut peneliti simpulkan sebagai bentuk dari Kevin Liliana memperlihatkan dirinya sebagai Miss International 2017 yang humble dan ramah kepada siapapun.

Konsep the law of unity berbicara tentang keselarasan antara kehidupan pribadi seseorang dengan sikap dan etika moralnya yang ditentukan dari merek tersebut (Haroen, 2014). Personal branding yang Kevin Liliana tampilkan sebagai Miss International 2017 juga ia terapkan di kehidupan pribadinya sehari-hari. Hal ini terbukti dari respon orang terdekatnya yang mengatakan bahwa Kevin Liliana adalah pribadi yang sangat humble dan juga mempunyai sikap yang sangat baik walaupun sudah mempunyai gelar Miss International 2017, kepribadiannya tidak pernah berubah dan tetap menjadi Kevin yang sama. Personal branding menurut Kevin Liliana tidak mengharuskan dirinya menjadi orang lain, cukup menjadi diri sendiri dengan mengolah segala kelebihan dan kekurangan yang dimiliki untuk menjadi sesuatu yang lebih baik dan mendatangkan hal baik bagi dirinya.

Dalam hal ini Kevin Liliana menunjukan adanya kesatuan antara kepribadian yang yang dirinya miliki sesuai dengan apa yang ditentukan oleh branding yang ia tunjukkan. Citra yang ingin Kevin Liliana tampilkan dalam membangun personal branding melalui media sosial Instagram sejalan dengan apa yang dilakukan di kehidupan sehariharinya. Kevin Liliana menampilkan aktivitas kesehariannya baik berupa keseharian sebagai Miss International 2017 ataupun kesehariannya sebagai pribadi di ruang akun Instagram-nya untuk menunjukan bahwa adanya kesatuan dengan apa yang ditampilkan kepublik dengan apa yang ia lakukan dikesehariannya tanpa ada rekayasa serta kepribadian mereka sebagai pribadi sejalan dengan apa yang ditentukan oleh personal branding-nya sebagai Miss International 2017.

Kevin Liliana dalam membangun personal branding-nya dengan arahan dari Yayasan Puteri Indonesia tetap menampilkan bagaimana pribadi Kevin di kehidupan nyata dan mengembangkannya sebagai suatu identitas dan citra yang ingin ditampilkan sebagai Miss International 2017. Hal tersebut serupa dengan yang dikatakan oleh Montoya bahwa citra pada personal brand yang ditampilkan harus mencerminkan kehidupan pribadinya secara nyata (Haroen, 2014). Salah satu contoh kesatuan dari personal branding Kevin Liliana adalah walaupun berhasil menjadi seorang beauty queen, panggilan "Eneng" atau "Neng" masih melekat pada diri Kevin Liliana, sehingga walaupun ia memiliki gelar Miss International 2017 panggilan tersebut masih terus ada dibenak orang lain. Julukan adalah personal brand yang terbentuk secara natural dari lingkungan di sekelilingnya berdasarkan keunikan atau kekhasan yang mudah diingat oleh orang lain (Haroen, 2014).

Kevin Liliana mempunyai panggilan "Eneng" atau "Neng" dikarenakan latar belakangnya yang merupakan asli Sunda, Jawa Barat dan tampilan fisik serta cara bicaranya yang menunjukkan ciri khas orang Sunda. Panggilan tersebut sebelumnya berasal dari keluarga dan orang terdekat, diikuti oleh khalayak lain seperti fans dan para followers-nya. Hal ini terlihat pada akun Instagram pribadinya @kevinlln, banyak pengguna lain yang meninggalkan komentar dengan memanggil dengan panggilan tersebut. Menurut Kevin Liliana, panggilan "Eneng" atau "Neng" yang melekat pada dirinya ini dikarenakan latar belakangnya yang merupakan orang Sunda dan kesan yang muncul di benak orang lain mengenai dirinya yang memang sangat menunjukkan kesan Sunda. Panggilan tersebut juga membantu Kevin Liliana dalam membangun personal branding-nya dalam hal mempermudah orang lain untuk mengenalnya.

Adanya panggilan tersebut menurut Dewi Haroen selaku pakar personal branding, merupakan hal yang baik karena panggilan tersebut dapat dijadikan jargon untuk membantu dalam hal meningkatkan awareness orang lain terhadap Kevin Liliana. Berdasarkan hal tersebut, peneliti menganalisis bahwa panggilan "Eneng" atau "Neng" yang melekat pada diri Kevin Liliana kurang mempresentasikan personal branding yang ia ingin tampilkan sebagai Miss International. Hal tersebut dikarenakan, menurut peneliti panggilan tersebut sangat umum dan tidak mempunyai ciri khas yang khusus sebagai sebuah "nickname" bagi Kevin Liliana dalam membangun personal branding-nya. Namun, peneliti setuju bila panggilan tersebut dapat membantu Kevin Liliana untuk lebih mudah dikenal oleh orang lain, dan sebagai suatu panggilan khusus yang dapat membuatnya lebih mudah berinteraksi 
dengan orang lain.

Konsep selanjutnya adalah keteguhan (the law of presistence), dimana setiap orang dalam membangun personal brandingnya penting untukmemperhatikantrend dantahapdemitahap, karena dalam prosesnya tentu membutuhkan waktu untuk bisa tumbuh (Haroen, 2014). Kevin Liliana dalam membangun personal branding-nya sebagai Miss International 2017, tidak merubah apapun mengenai apa yang ingin ia tampilkan sebagai identitas dirinya. Dari awal menjabat sebagai Puteri Indonesia Lingkungan hingga memenangkan ajang Miss International 2017, identitas yang ingin Kevin Liliana tampilkan sebagai personal branding tetaplah sama dan tidak ada yang ia ubah bahkan sampai sekarang. Kevin Liliana tetap teguh pada personal branding yang memang dari awal ia ingin tampilkan. Hal tersebut sesuai dengan ungkapan Montoya bahwa keteguhan sangat penting dilakukan pada personal brand yang sejak awal sudah dibentuk, tanpa merasa ragu maupun berniat untuk merubahnya (Haroen, 2014).

Konsep yang terakhir adalah the law of goodwill. Konsep ini menekankan pada hasil dari sebuah personal brand, dimana apabila seseorang dipersepsikan secara positif maka akan hasilnya akan baik dan bertahap lebih lama (Haroen, 2014). Kevin Liliana dalam menjaga nama baiknya sebagai Miss International 2017, selalu menampilkan sesuatu yang positif dan menunjukkan sikap ramah kepada siapa saja serta tidak menggunakan bahasa kasar dalam berkomunikasi dengan siapapun baik di kehidupan sehari-sehari maupun di akun media sosial Instagram pribadinya@kevinlln.

Kevin Liliana selalu menampilkan kontenkonten positif melalui apa yang ia unggah di akun Instagramnya@kevinlln,menggunakan bahasa yang sopan di setiap caption yang ia buat dan pada saat membalas komentar orang lain. Selain itu, Kevin Liliana juga memperhatikan cara berpakaiannya dimana selalu menggunakan pakaian yang masih dikategorikan sopan sesuai dengan personal branding-nya sebagai beauty queen yang soft. Hal tersebut menurut analisis peneliti, termasuk kedalam hal untuk menjaga nama baiknya agar terhindar dari persepsi negatif. Dalam menjaga nama baiknya sebagai Miss International 2017, Kevin Liliana juga berusaha untuk selalu menjaga kerja sama yang baik dengan pihakpihak yang melakukan kerja sama dengan nya agar pihak tersebut puas dan mendatangnya persepsi yang baik tentang Kevin Liliana yang tentunya akan berdampak positif bagi personal branding-nya. Hal ini terlihat juga pada akun Instagramnya @kevinlln yang selalu professional dalam mengunggah hal yang bersifat komersial dimana Kevin Liliana tidak hanya mengunggahnya sekali tapi berkali-kali di feed Instagramnya dan juga di Insta Story.

Apa yang dilakukan Kevin Liliana tersebut dikarenakan menurutnya sangat penting menjaga nama baik di benak orang lain, terutama para pihak yang melakukan kerja sama dengan dirinya dan merupakan bentuk dari keprofesionalitasnya. Menurut Kevin Liliana, dengan kepuasan dari pihak-pihak tersebut akan mendatangkan hal yang baik bagi karirnya dimana dapat menambah kesempatan mendatangkan minat bagi pihak lain untuk bekerja sama dengannya.

Keprofesionalitas Kevin Liliana sebagai Miss International 2017 maupun sebagai seorang brand ambassador ini peneliti rasa cukup memenuhi konsep good will dalam membangun personal branding. Hal ini dapat dilihat dari banyaknya kerja sama yang Kevin Liliana lakukan selama menjabat sebagai Miss International 2017, mulai dari kerja sama untuk kegiatan sosial sampai dengan perusahan produk. Selain itu, kerja sama tersebut terjadi dalam jangka waktu yang panjang.

Berdasarkan penjabaran delapan konsep personal branding dari Peter Montoya tersebut, Kevin Liliana memiliki kedelapan konsep tersebut yaitu spesialisasi (the law of specialization), kepemimpinan (the law of leadership), kepribadian(the law ofpersonality), perbedaan (the law of distinctiveness), the law of visibility, kesatuan (the law of unity), keteguhan (the law of persistence), dan nama baik (the law of goodwill). Namun dalam personal brandingnya, Kevin Liliana hanya mengaplikasikan tujuh dari delapan konsep dalam membangun personal branding-nya sebagai Miss International 2017. Hal ini dikarenakan dalam membangun personal branding-nya sebagai Miss International 2017, Kevin Liliana tidak menampilkan segi kepemimpinan (the law of leadership).

Instagram merupakan salah satu media popular yang dianggap memiliki platform cukup praktis yang berguna untuk melakukan interaksi dan memnciptakan sebuah persepsi. 


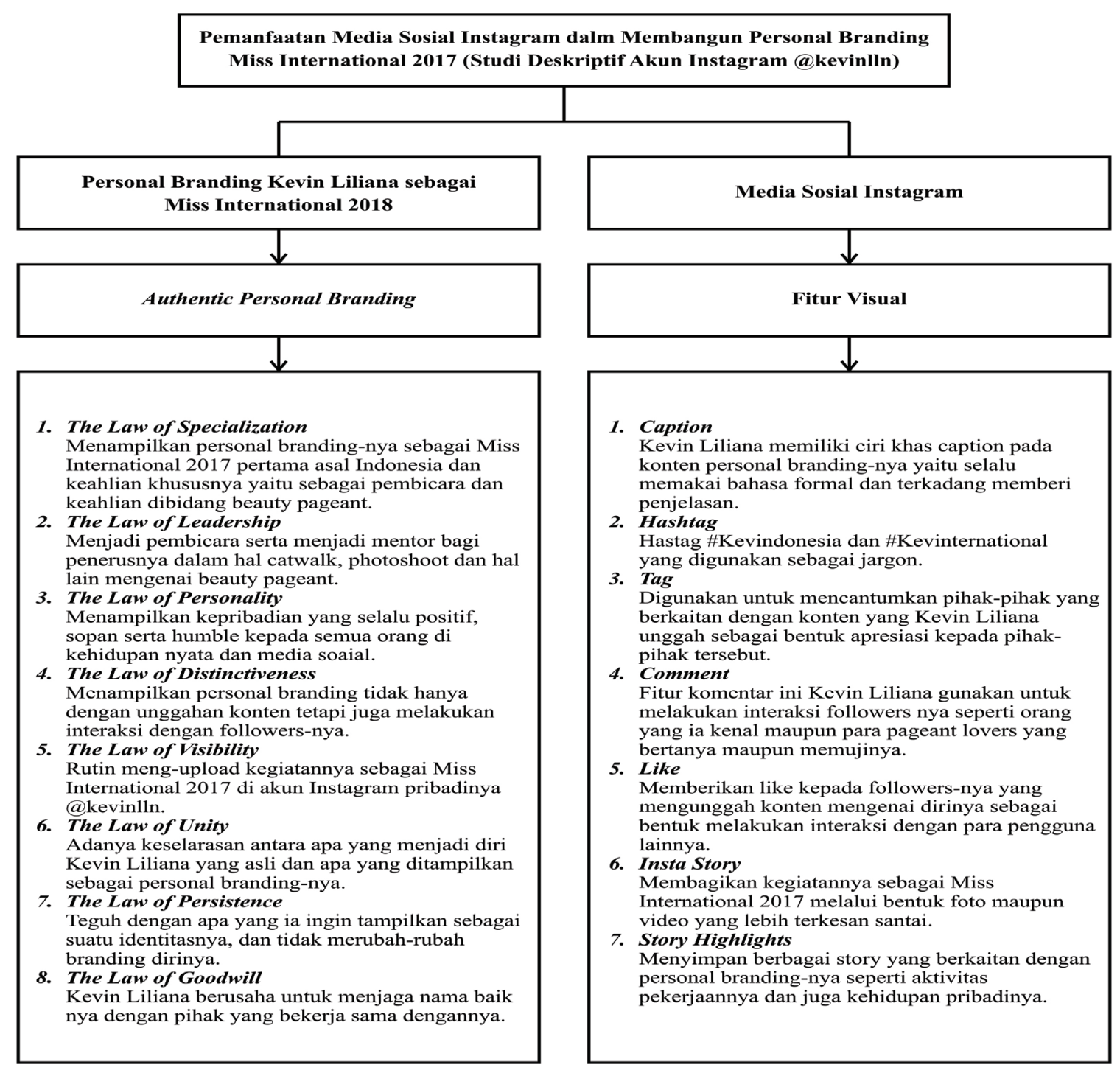

Sumber: Data Olahan Penulis, 2019

\section{Gambar 2 Model Pemanfaatan Media Sosial Instagram dalam Membangun Personal Branding Miss International 2017}

Hal tersebutlah yang menjadi alasan Kevin Liliana membangun personal brandingnya sebagai Miss International 2017 melalu akun@kevinlln. Banyak fitur yang dimiliki oleh Instagram, hal ini sangat membantu dan mendukung Kevin Liliana dalam membangun personal branding-nya.

Berdasarkan hasil penelitian yang dilakukan peneliti bahwa informan penelitian yaitu Kevin Liliana selaku Miss International 2017 membangun personal branding-nya dengan memanfaatkan fitur-fitur yang ada di dalam instagram seperti caption, comment, hashtag, tag, insta story dan story highlights.
Kevin Liliana menggunakan Instagram sebagai media untuk mengekspresikan dirinya, menampilkan bagaimana kepribadiannya dan personal branding-nya sebagai seorang Miss International 2017. Kevin Liliana berusaha untuk mengkomunikasikan apa yang menjadi personal branding-nya melalui Instagram pribadinya@kevinlln dengan cara memanfaatkan fitur Instagram tersebut dan selalu mengunggah segala aktivitasnya baik kegiatan kesehariannya sebagai Miss International maupun kehidupan pribadinya. Selain itu, Kevin Liliana juga melakukan interaksi yang baik dengan para followers-nya 
agar dapat membentuk persepsi khalayak yang positif.

Menurutanalisispeneliti,personalbranding yang Kevin Liliana lakukan sebagai Miss International 2017 sudah dapat dikategorikan berhasil. Pernyataan peneliti ini didukung juga oleh pernyataan dari orang terdekatnya yaitu Nina Nur Azizah selaku Chaperone dan Staff Yayasan Puteri Indonesia yang membantu Kevin Liliana dalam membangun personal brandingnya. Nina Nur Azizah mengungkapkan bahwa menurutnya Kevin Liliana sudah dengan optimal menjalankan personal branding-nya sebagai seorang Miss International 2017, sesuai dengan apa yang diarahkan dan ia juga berpendapat bahwa Kevin Liliana berhasil membangun personal branding-nya sebagai Miss International 2017.

Berdasarkan analisa keseluruhan yang dilakukan, peneliti menyimpulkan personal branding Kevin Liliana selaku Miss International 2017 melalui media sosial Instagram melalui model pada gambar 2 .

\section{SIMPULAN}

Kevin Liliana mendasari personal branding-nya secara authentic, dimana terdapat keselarasan antara apa yang ia tampilkan di media sosial dan kehidupan aslinya. Personal branding yang Kevin Liliana tampilkan sebagai Miss International 2017 yaitu sebagai beauty queen yang soft, humble, dan menonjolkan sisi behavior-nya. Personal branding yang dilakukan oleh Kevin Liliana sebagai Miss International 2017 pada akun Instagram pribadinya @kevinlln ini secara keseluruhan sesuai dengan delapan konsep personal branding yang dari Peter Montoya, yaitu spesialisasi (the law of specialization), kepemimpinan (the law of leadership), kepribadian (the law of personality), perbedaan (the law of distinctiveness), the law of visibility, kesatuan (the law of unity), keteguhan (the law of persistence), dan nama baik (the law of goodwill).

Dalam personal branding-nya, Kevin Liliana hanya mengaplikasikan tujuh dari delapan konsep dalam membangun personal branding-nya sebagai Miss International 2017. Hal ini dikarenakan dalam membangun personal branding-nya sebagai Miss International 2017, Kevin Liliana tidak menampilkan segi kepemimpinan (the law of leadership) pada konten yang ia tampilkan sebagai personal branding-nya. Secara keseluruhan personal branding Kevin Liliana membangun personal branding-nya selaras dengan kepribadian maupun karakternya dan juga dibantu oleh Yayasan Puteri Indonesia (YPI) dalam mengembangkan apa yang menjadi kelebihan dan spesialisasinya dalam membangun personal branding sebagai Miss International 2017.

Selain konsep personal branding, dalam membangun personal branding di Instagram, Kevin Liliana juga memanfaatkan fitur yang ada di dalamnya yaitu caption, like, comment, hashtag, tag, Instagram stories dan story highlight. Kevin Liliana membangun personal branding melalui Instagram pribadinya @ kevinlln ini tidak hanya berupa mengunggah konten personal branding, tetapi juga dengan berinteraksi dengan para pengikutnya (followers) melalui fitur Instagram agar pesan personal branding-nya dapat lebih cepat dan mudah tersampaikan. Dalam membangun personal branding-nya di Instagram, Kevin Liliana tidak merasakan kesulitan, walaupun ada beberapa hal seperti hate speech yang menjadi ancaman bagi personal branding-nya, tapi hal tersebut tidak ia jadikan halangan dan kesulitan dalam membangun personal branding melalui akunnya.

Secara keseluruhan, Kevin Liliana berhasil melakukan personal branding di Instagram pribadinya, walaupun terdapat beberapa kekurangan. Kekurangan tersebut berupa, engagement pada konten kegiatan sosial yang merupakan konten personal branding-nya tidak lebih banyak mendapat respon seperti like dan comment dari pengguna lain. Selain itu, kekurangan lainnya adalah Kevin Liliana tidak konsisten dalam penggunaan hashtag \#Kevindonesia dan \#Kevinternational yang dimana hanya ia gunakan di awal menjabat.

Personal branding yang dibangun oleh Kevin Liliana dalam media sosialnya juga menghadirkan cukup banyak manfaat dalam kehidupannya. Kehadiran media sosial dengan sifatnya yang personal sangat membantu setiap brand dalam menunjukkan keunggulan kepribadiannya serta menjadi lebih manusiawi Kevin Liliana mendapat banyak peluang untuk menjalin kerja sama dengan berbagai pihak perusahaan maupun brand tertentu, hingga menjadi brand ambassador yang dimana 
tentunya mendatangkan perkembangan bagi karirnya. Tidak hanya hal tersebut, setelah selesai menjabat sebagai Miss International 2017, Kevin Liliana juga langsung mendapatkan tawaran menjadi Reporter dan News Presenter di Liputan 6 SCTV berkat konten personal branding yang ia unggah mengenai keahliannya dalam menjadi pembicara di berbagai kegiatan.

Bagi peneliti yang tertarik untuk membahas topik serupa dengan peneliti dianjurkan untuk lebih spesifik membahas kepribadian authentic serta konsep yang ada dalam pembentukan personal branding-nya. Selain itu dapat juga membahas bagaimana sebuah personalbranding dapat dibangun dengan mengoptimalkan fiturfitur yang dimiliki oleh Instagram. Peneliti berharap agar penelitian dapat bermanfaat serta membantu peneliti selanjutnya yang ingin membahas mengenai pemanfaatan Instagran dalam membangun personal branding. Selain itu, untuk peneliti selanjutnya yang ingin meneliti topik serupa disarankan untuk membahas pemanfaatan media sosial lainnya dalam membangun personal branding, seperti Youtube ataupun Twitter.

Bagi para public figure, diharapkan dalam membangun personal branding melalui media sosial tertentu, disarankan agar bisa lebih memperhatikan konten-konten yang akan ia unggah ke akun pribadinya masing-masing. Konten-konten tersebut juga akan lebih baik dapat terus menerus memuat konten yang positif dan sesuai dengan apa yang ingin mereka tampilkan dalam personal branding-nya. Hal ini menjadi penting karena diharapkan akan mendatangkan suatu engagement dari pengguna media sosial lain terhadap konten tersebut. Selain itu, peneliti menyarankan agar siapapun yang ingin membangun personal branding melalui media sosial khususnya Instagram, agar mereka lebih dapat memanfaatkan fiturfitur yang sudah tersedia agar pesan personal branding yang ingin disampaikan dapat lebih mudah tersampaikan.

\section{DAFTAR PUSTAKA}

Abbas, M. R. (2014). Panduan optimalisasi media sosialuntuk kementrian perdagangan RI. Jakarta: Kementerian Perdagangan RI.

Butar, C. R. B., \& Ali, D. S. F. (2018). Strategi personal branding selebgram non selebriti. Jurnal PRofesi Humas, 2(2), 86-101.
Databoks. (2018). 2018, jumlah penduduk Indonesia mencapai 265 juta jiwa. Retrieved from https://databoks.katadata. co.id/datapublish/2018/05/18/2018jumlah-penduduk-indonesia-mencapai265-juta-jiwa

Fuad, A., \& Nugroho, K. S. (2014). Panduan praktis penelitian kualitatif. Yogyakarta: Graha Ilmu.

Gunawan, I. (2013). Metode penelitian kualitatif teori \& praktek. Jakarta: Bumi Aksara.

Haroen, D. (2014). Personal branding: kunci kesuksesan berkiprah di dunia politik. Jakarta: Gramedia.

Haroen, D. (2018). Personal branding Sukses Karier di Era Milenial. Tangerang Selatan: DH Media.

Heikkurinen, A. (2016). Personal branding practices of adolescents on Instagram. LUT School of Business and Management. Retrieved from https://lutpub.lut. fi/bitstream/handle/10024/124390/ kandidaatintutkielma heikkurinen anna. pdf? sequence $=2 \&$ is Allowed $=y$

Jeko. (2018). Instagram kantongi 1 miliar pengguna di seluruh dunia. Retrieved November 2, 2018, from https://www. liputan6.com/tekno/read/3564956/ instagram-kantongi-1-miliar-pengguna-diseluruh-dunia

Noor, J. (2015). Metodologi penelitian: skripsi, tesis, disertasi, dan karya ilmiah. Jakarta: Prenada Media Group.

Ono, N. H., Romli, R., \& Nugraha, A. R. (2019). Strategi courtyard by Marriott Bandung Dago dalam mengkomunikasikan brand personality melalui Instagram. Jurnal Mediakom, 3(1), 84-106. https://doi.org/ http://dx.doi.org/10.35760/mkm.2019. v3i1.1984

Pratama, A. N. (2018). Hari ini dalam sejarah: aplikasi Instagram dirilis... Retrieved March 2, 2020, from https://tekno.kompas.com/ $\mathrm{read} / 2018 / 10 / 06 / 10512437 /$ hari-ini-dalamsejarah-aplikasi-instagram-dirilis?page $=$ all

Putri, N. E., Hakim, N., \& Yamin, M. (2016). Ecologicall Footprint and Biocapacity Analysis for Flooding Prevention in South Sumatera. Jurnal Mimbar, 32(1), 58-64.

Soraya, I. (2017). Personal branding Laudya Cynthia Bella melalui Instagram. Jurnal Komunikasi, 8(2), 30-38. https://doi.org/ 
https://doi.org/10.31294/jkom.v8i2.2654

Sugiyono.(2013). Metode penelitian kuantitatif, kualitatif dan $r \& d$. Bandung: Alfabeta.

Suwendra, I. W. (2018). Metode penelitian kualitatif dalam ilmu sosial, pendidikan, kebudayan dan keagamaan. Bandung: Nilacakra.

Tamimy, M. F. (2017). Sharing-mu, personal branding-mu. Jakarta: VisiMedia Pustaka. Usman, H., \& Akbar, P. S. (2006). Metodologi penelitian sosial. Jakarta: PT. Bumi Aksara. We Are Social. (2018). Global digital report 2018: world's internet users pass the 4 billion mark. Retrieved from https:// digitalreport.wearesocial.com/ 